\title{
Keterkaitan Grup Spesial Uniter dengan Grup Spesial Ortogonal
}

\author{
Nuraesa Nufus Faurani ${ }^{1}$, Ema Carnia $^{1}$, Agus Supriatna ${ }^{1}$ \\ Departemen Matematika FMIPA Universitas Padjadjaran \\ Jl. Raya Bandung-Sumedang Km.21, Jatinangor \\ Email: ecafaurani@gmail.com
}

\begin{abstract}
ABSTRAK
Grup Lie merupakan grup yang berisikan matriks yang merepresentasikan pergerakan atau perputaran suatu titik terhadap sumbu koordinat atau sumbu koordinat terhadap suatu titik. Grup spesial uniter dan grup spesial ortogonal merupakan contoh grup Lie. Dalam kajian fisika, grup spesial uniter dimensi dua $(S U(2))$ merepresentasikan rotasi elektron terhadap pusat rotasinya. Sedangkan grup spesial ortogonal dimensi tiga (SO(3)) merepresentasikan rotasi elektron terhadap inti atom. Dalam paper ini, akan dikaji keterkaitan antara kedua grup ini dengan menggunakan Teorema Isomorfisma sehingga diperolah hasil bahwa terdapat homomorfisma surjektif dari grup $S U(2)$ ke grup $S O(3)$ kemudian dapat ditunjukkan bahwa $S U(2) / \operatorname{Ker}(\varphi)$ isomorfik dengan $\mathrm{SO}(3)$.
\end{abstract}

Kata Kunci: grup spesial ortogonal, grup spesial uniter, isomorfisma

\section{ABSTRACT}

Lie Group is a group with a matrix that represents the movement or rotation of a point on the axis or the axis to a point. Special unitary group and special orthogonal group is an example of a Lie group. In the study of physics, special unitary group of two-dimensional (SU (2)) represents the electron's rotation to the center of rotation. Meanwhile, special orthogonal group of three-dimensional (SO (3)) represents the rotation of electrons to the nucleus. In this paper, will be studied the relationship between the two groups by using Isomorphism Theorem so that obtained results that there is a surjective homomorphism of the group SU (2) to the group SO (3) then it can be shown that $S U(2) / \operatorname{Ker}(\varphi)$ is isomorphic to SO (3).

Keywords: special orthogonal group, special unitary group, isomorphism

\section{Pendahuluan}

Teori grup muncul diawal abad ke-19 dan berasal dari tiga bidang ilmu dasar matematika, yaitu persamaan aljabar, teori bilangan, dan geometri (Baumslag, B. et al., 1968). Teori grup secara khusus membahas mengenai grup, mulai dari definisi grup, sifat-sifat grup, macam-macam grup, hingga konstruksi struktur grup lain. Kegunaan grup sangatlah banyak dan tidak terbatas diaplikasikan dalam ilmu matematika saja, namun dapat pula diaplikasikan untuk keilmuan lain. Teori grup merupakan salah satu teori dalam ilmu matematika yang dapat diaplikasikan pada beberapa bidang keilmuan, salah satunya fisika. Dalam ilmu fisika, teori grup dapat membantu 
menjelaskan kesimetrisan suatu benda fisis, salah satunya adalah teori rotasi elektron suatu atom (Woit P., 2016).

Elektron berotasi terhadap inti atom menyebabkan terjadinya momentum sudut orbital. Selain melakukan rotasi terhadap inti atom, elektron juga berotasi terhadap pusat rotasinya, yang menyebabkan munculnya momentum spin (Rosyid dan Fachrani, M., 2005). Dalam teori grup, momentum sudut dapat direpresentasikan dalam grup spesial ortogonal dimensi tiga atau $S O(3)$, sedangkan momentum spin, dapat direpresentasikan dalam grup spesial uniter dimensi dua atau $S U(2)$ (Woit P., 2016).

Bila dalam fisika sudah jelas bahwa momentum spin dan momentum sudut adalah kajian mengenai sifat rotasi elektron, kini akan ditinjau dari pandangan matematika mengenai struktur grup yang merepresentasikan momentum sudut orbital dan momentum spin agar terlihat teori grup juga dapat digunakan untuk mengidentifikasi struktur-struktur grup yang saling berkaitan.

\section{Metode Penelitian}

Metode yang digunakan dalam paper ini adalah studi literatur yang dilakukan dengan mengumpulkan literatur-literatur yang sesuai dengan kajian yang dibahas. Sumber yang digunakan berasal dari buku teks, jurnal maupun artikel di internet. Referensi utama paper ini merujuk pada artikel Neumainer, A. dan Westra D., 2008 mengenai keterkaitan grup spesial uniter dimensi dua dengan grup spesial ortogonal dimensi tiga. Kemudian dibahas dan dibuktikan lebih lanjut dari sudut pandang Matematika khususnya struktur aljabar. Dimulai dari pendefinisian objek penelitian yaitu grup spesial uniter dimensi dua dan grup spesial ortogonal dimensi tiga. Kemudian diulas sifat-sifat dari masing-masing grup tersebut.

Selanjutnya, untuk menunjukkan bahwa pemetaan dari $S U(2)$ ke $S O(3)$ isomorfisma, maka harus dilakukan beberapa tahap diantaranya adalah membentuk pemetaan $\varphi$ dari grup $S U(2)$ ke grup $S O(3)$, kemudian membuktikan bahwa pemetaan $\varphi$ merupakan homomorfisma surjektif, selanjutnya mencari kernel dari pemetaan $\varphi$ yang dilanjut dengan proses konstruksi grup kuosien, yaitu grup $S U(2) / \operatorname{Ker}(\varphi)$. Setelah itu menunjukkan bahwa grup $S U(2) / \operatorname{Ker}(\varphi)$ dan grup $S O(3)$ isomorfik dengan menggunakan teorema fundamental homomorfisma.

\section{Hasil dan Pembahasan}

Hasil serta pembahasan dari paper ini ialah menunjukkan serta membuktikan adanya keterkaitan antara kedua grup berdasarkan ilmu struktur aljabar dalam matematika.

\subsection{Grup $S U(2)$ dan $S O(3)$ serta Sifat-sifatnya}

Elemen dari grup uniter merupakan matriks persegi dengan elemen merupakan bilangan kompleks yang kemudian dinotasikan $U$ dan memenuhi $U^{*} U=I$ atau $U^{*}=U^{-1}$ dengan $U^{*}, U^{-1}$, dan $I$ masing-masing merupakan matriks transpos konjugat dari $U$, matriks invers dari $U$, dan matriks identitas. Matriks dengan ketentuan tersebut dikenal dengan matriks uniter.

Matriks-matriks uniter berordo $2 \times 2$ yang disertai dengan perkalian matriks biasa merupakan sebuah grup yang dikenal sebagai grup uniter $U(2)$.

Grup uniter yang memiliki nilai determinan 1 disertai perkalian matriks biasa merupakan sebuah grup yang dinamakan grup spesial uniter yang dinotasikan $S U(2)=\{U \in U(2)$; det $(U)=1\}$. 
Bentuk umum dari grup spesial uniter dimensi dua yang berisi matriks uniter $2 \times 2$ dapat ditulis $S U(2)=\left\{U=\left[\begin{array}{cc}a & b \\ -b^{*} & a^{*}\end{array}\right] \mid U^{*}=U^{-1}, \operatorname{det}(U)=1, a, b \in \mathbb{C}\right\}$

Akan diperlihatkan bahwa grup $S U(2)$ bukan merupakan grup abelian atau tidak berlaku sifat komutatif pada grup tersebut terhadap operasi yang ada pada grup tersebut, yaitu operasi perkalian matriks biasa. Hal ini dikarenakan grup $S U(2)$ berisikan matriks, sedangkan yang telah diketahui bahwa matriks tidak memiliki sifat komutatif. Perkalian dari $U_{1} U_{2}$ dan $U_{2} U_{1}$ berbeda atau dengan kata lain $U_{1} U_{2} \neq U_{2} U_{1}$. Sehingga dapat disimpulkan bahwa grup $S U(2)$ bukan merupakan grup abelian.

Selanjutnya akan dipilih subgrup dari $S U(2)$ yang kemudian akan diselidiki juga apakah subgrup tersebut merupakan grup siklis. Misalkan dipilih suatu subset dari grup $S U(2)$, yaitu himpunan $G$ sebagai berikut: $G=\left\{\left[\begin{array}{ll}1 & 0 \\ 0 & 1\end{array}\right],\left[\begin{array}{cc}-1 & 0 \\ 0 & -1\end{array}\right],\left[\begin{array}{cc}0 & 1 \\ -1 & 0\end{array}\right],\left[\begin{array}{cc}0 & -1 \\ 1 & 0\end{array}\right]\right\}$.

Kemudian akan diperiksa apakah $G$ merupakan grup siklis. Untuk memeriksa hal tersebut, perlu dicari generator dari setiap elemen di $G$. Sebuah elemen di $G$ dikatakan sebagai generator apabila memenuhi $G=\langle a\rangle=\left\{a^{n} \mid a \in G, n \in \mathbb{Z}^{+}\right\}$. Apabila tidak ada generator pada $G$, maka $G$ bukanlah grup siklis.

Generator dari $G$ yaitu $\left\langle\left[\begin{array}{cc}0 & -1 \\ 1 & 0\end{array}\right]\right\rangle$ dan $\left\langle\left[\begin{array}{cc}0 & 1 \\ -1 & 0\end{array}\right]\right\rangle$. Elemen $G$ yang menjadi generator merupakan elemen yang saling invers. Artinya matriks $\left[\begin{array}{cc}0 & -1 \\ 1 & 0\end{array}\right]$ merupakan invers dari matriks $\left[\begin{array}{cc}0 & 1 \\ -1 & 0\end{array}\right]$. Karena $G$ memilliki generator, maka $G$ merupakan grup siklis.

Kemudian selain $G$, diambil subgrup lain yaitu $H=\left\{\left[\begin{array}{ll}1 & 0 \\ 0 & 1\end{array}\right],\left[\begin{array}{cc}-1 & 0 \\ 0 & -1\end{array}\right]\right\}$ yang merupakan subgrup dari $G$ dan otomatis menjadi subgrup dari $S U(2)$. Kemudian selanjutnya $H$ dikatakan merupakan subgrup normal dari $G$ karena telah diperiksa dan memenuhi apabila perkalian dari invers elemen grupnya, subgrupnya, dan elemen grupnya adalah subset dari subgrupnya. Dengan demikian, maka $H$ merupakan subgrup normal. Penjelasan di atas dapat dituliskan dengan $U^{-1} H U \subset H$ untuk setiap $U \in S U(2)$.

Selanjutnya karena sudah didapatkan subgrup normal, maka berdasarkan definisi grup kuosien, dapat dikonstruksi sebuah grup kuosien dari $S U(2)$ oleh $H$ yaitu $S U(2) / H$ dengan elemenelemennya yaitu $S U(2) /_{H}=\{U H \mid U \in S U(2)\}$.

Berdasarkan uraian mengenai sifat-sifat grup $S U(2)$ di atas, maka dapat disimpulkan bahwa grup $S U(2)$ bukan merupakan grup abelian, ada subgrup dari $S U(2)$ yang merupakan grup siklis, dan grup $S U(2)$ dapat dikonstruksi menjadi grup kuosien oleh subgrup normalnya, yaitu $H=$ $\left\{\left[\begin{array}{ll}1 & 0 \\ 0 & 1\end{array}\right],\left[\begin{array}{cc}-1 & 0 \\ 0 & -1\end{array}\right]\right\}$.

Selanjutnya akan dijelaskan mengenai grup spesial ortogonal dimensi tiga. Elemen dari grup ortogonal merupakan matriks persegi dengan elemen merupakan bilangan real yang kemudian dinotasikan $R$ dan memenuhi $R^{T} R=R R^{T}=I$ atau $R^{T}=R^{-1}$ dengan $R^{T}, R^{-1}$, dan $I$ masing-masing merupakan matriks transpos dari $R$, matriks invers dari $R$, dan matriks identitas. Matriks dengan ketentuan tersebut dikenal dengan matriks ortogonal.

Matriks-matriks ortogonal berordo $3 \times 3$ yang disertai dengan perkalian matriks biasa merupakan sebuah grup yang dikenal sebagai grup ortogonal $O(3)$.

Grup ortogonal yang memiliki nilai determinan 1 disertai perkalian matriks biasa merupakan sebuah grup yang dinamakan grup spesial ortogonal yang dinotasikan $S O(3)=\{R \in O(3) ; \operatorname{det}(R)=$ $1\}$. 
Bentuk umum dari grup spesial ortogonal dimensi tiga yang berisi matriks ortogonal $3 \times 3$ dapat ditulis $S O(3)=\left\{R=\left[\begin{array}{ccc}\operatorname{Re}\left(a^{2}-b^{2}\right) & \operatorname{Im}\left(a^{2}+b^{2}\right) & 2 \operatorname{Re}(a b) \\ -\operatorname{Im}\left(a^{2}-b^{2}\right) & \operatorname{Re}\left(a^{2}+b^{2}\right) & 2 \operatorname{Im}(a b) \\ 2 \operatorname{Re}\left(a b^{*}\right) & 2 \operatorname{Im}\left(a b^{*}\right) & |a|^{2}-|b|^{2}\end{array}\right]\right\}$.

Sama seperti grup $S U(2)$, akan diperlihatkan bahwa grup $S O(3)$ juga bukan merupakan grup abelian atau berlaku sifat komutatif pada grup tersebut terhadap operasi yang ada pada grup tersebut, yaitu operasi perkalian matriks biasa. Hal ini dikarenakan grup $S O(3)$ berisikan matriks, sedangkan yang telah diketahui bahwa matriks tidak memiliki sifat komutatif. Perkalian dari $R_{1} R_{2}$ dan $R_{2} R_{1}$ berbeda atau dengan kata lain $R_{1} R_{2} \neq R_{2} R_{1}$. Sehingga dapat disimpulkan bahwa grup $S O$ (3) bukan merupakan grup abelian.

Selanjutnya akan dipilih subgrup dari $S O(3)$ yang kemudian akan diselidiki juga apakah subgrup tersebut merupakan grup siklis. Misalkan dipilih suatu subset dari grup SO(3), yaitu himpunan $N$ sebagai berikut: $N=\left\{\left[\begin{array}{lll}1 & 0 & 0 \\ 0 & 1 & 0 \\ 0 & 0 & 1\end{array}\right],\left[\begin{array}{ccc}-1 & 0 & 0 \\ 0 & 1 & 0 \\ 0 & 0 & -1\end{array}\right]\right\}$.

Kemudian akan diperiksa apakah $N$ merupakan grup siklis. Untuk memeriksa hal tersebut, perlu dicari generator dari setiap elemen di $N$. Sebuah elemen di $N$ dikatakan sebagai generator apabila memenuhi $N=<a>=\left\{a^{n} \mid a \in N, n \in \mathbb{Z}^{+}\right\}$. Dalam $N$ ternyata tidak terdapat generator, maka dapat disimpulkan bahwa contoh grup $S O(3)$ yang diambil bukan merupakan grup siklis.

Selanjutnya akan dicari subgrup normal pada grup $S O(3)$ dengan cara mencari subgrup yang memenuhi perkalian dari invers elemen grupnya, subgrupnya, dan elemen grupnya adalah subset dari subgrupnya. Jika demikian, maka subgrupnya merupakan subgrup normal. Penjelasan di atas dapat dituliskan dengan $R^{-1} N R \subset N$ untuk setiap $R \in S O(3)$. Karena setiap elemen identitas apabila dikalikan dengan semua elemen di $S O(3)$ akan menghasilkan elemen itu sendiri yang otomatis merupakan elemen di $S O(3)$, sehingga dapat dikatakan bahwa subgrup normal dari grup $S O(3)$ adalah elemen identitasnya, yaitu $\left[\begin{array}{lll}1 & 0 & 0 \\ 0 & 1 & 0 \\ 0 & 0 & 1\end{array}\right]$.

Selanjutnya karena sudah didapatkan subgrup normal, maka berdasarkan definisi grup kuosien, dapat dikonstruksi grup kuosien dari $S O(3)$ oleh matriks identitasnya yang dinotasikan dengan $I$, yaitu $S O(3) / I$ dengan elemen-elemennya yaitu $S O(3) / I=\{R I \mid R \in S O(3)\}$. Apabila melihat grup kuesien tersebut, maka dapar dikatakan bahwa grup kuosien tersebut sama dengan grup SO(3) itu sendiri.

Berdasarkan uraian mengenai sifat-sifat grup $S O(3)$ di atas, maka dapat disimpulkan bahwa grup $S O(3)$ bukan merupakan grup abelian, kemudian salah satu subgrup dari $S O$ (3) yang diambil bukan merupakan grup siklis, dan grup $S O(3)$ memiliki subgrup normal yaitu identitasnya sendiri sehingga grup kuosien yang terbentuk akan sama dengan grup $S O(3)$ itu sendiri.

\subsection{Keterkaitan Grup $S U(2)$ dengan Grup $S O(3)$}

Untuk mengetahui keterkaitan antara dua grup, maka digunakan isomorfisma sebagai metode formal untuk menentukan apakah ada kesamaan struktur antara dua grup yang berbeda. Dalam penulisan kali ini akan digunakan isomorfisma yang berkaitan dengan teorema isomorfisma I atau biasa disebut teorema fundamental homomorfisma.

Untuk membuktikan menggunakan teorema fundamental homomorfisma, langkah awal dalam pembuktian teorema fundamental homomorfisma adalah membentuk pemetaan, didefinisikan pemetaan $\varphi$ dari grup $S U(2)$ ke grup $S O(3)$. Pemetaan ini dinotasikan $\varphi: S U(2) \rightarrow S O(3)$. Karena 
sebelumnya telah diketahui bentuk umum dari masing-masing grup, maka pemetaan elemen grupnya dapat ditulis $\varphi\left(\left[\begin{array}{cc}a & b \\ -b^{*} & a^{*}\end{array}\right]\right)=\left[\begin{array}{ccc}\operatorname{Re}\left(a^{2}-b^{2}\right) & \operatorname{Im}\left(a^{2}+b^{2}\right) & 2 \operatorname{Re}(a b) \\ -\operatorname{Im}\left(a^{2}-b^{2}\right) & \operatorname{Re}\left(a^{2}+b^{2}\right) & 2 \operatorname{Im}(a b) \\ 2 \operatorname{Re}\left(a b^{*}\right) & 2 \operatorname{Im}\left(a b^{*}\right) & |a|^{2}-|b|^{2}\end{array}\right]$ atau dapat pula ditulis dengan $\left[\begin{array}{cc}a & b \\ -b^{*} & a^{*}\end{array}\right] \mapsto\left[\begin{array}{ccc}\operatorname{Re}\left(a^{2}-b^{2}\right) & \operatorname{Im}\left(a^{2}+b^{2}\right) & 2 \operatorname{Re}(a b) \\ -\operatorname{Im}\left(a^{2}-b^{2}\right) & \operatorname{Re}\left(a^{2}+b^{2}\right) & 2 \operatorname{Im}(a b) \\ 2 \operatorname{Re}\left(a b^{*}\right) & 2 \operatorname{Im}\left(a b^{*}\right) & |a|^{2}-|b|^{2}\end{array}\right]$.

Kemudian harus dibuktikan bahwa pemetaan tersebut terdefinisi dengan baik, pemetaan homomorfisma, dan pemetaan surjektif.

Akan ditunjukkan bahwa pemetaan $\varphi$ terdefinisi dengan baik. Misalkan untuk sembarang $U_{1}, U_{2} \in S U(2)$ dengan $U_{1}=U_{2}$, maka harus berlaku $\varphi\left(U_{1}\right)=\varphi\left(U_{2}\right)$. Karena $U \in S U(2)$ dan matriks dalam $S U(2)$ memiliki entri-entri bilangan kompleks, maka apabila $a, b$ merupakan entri-entri matriks $U$, didapat $a, b \in \mathbb{C}$. Karena matriks dalam $S O(3)$ memiliki entri-entri bilangan real dan bilangan real merupakan bagian dari bilangan kompleks, maka apabila dibuat matriks $3 \times 3$ dengan entri-entri $a, b \in \mathbb{C}$, didapat $\varphi(U) \in S O(3)$. Berdasarkan penjabaran di atas, terdapat $\varphi\left(U_{1}\right)$ dan $\varphi\left(U_{2}\right)$ untuk sembarang $U_{1}$ dan $U_{2}$. Karena $U_{1}=U_{2}$, maka entri-entri di $U_{1}$ sama dengan entri-entri di $U_{2}$, akibatnya $\varphi\left(U_{1}\right)=\varphi\left(U_{2}\right)$. Jadi, terbukti bahwa pemetaan $\varphi$ terdefinisi dengan baik.

Selanjutnya haruslah ditunjukkan bahwa pemetaan $\varphi$ homomorfisma. Misalkan elemen sembarang $U_{1}, U_{2} \in S U(2)$ dengan $U_{1}=\left[\begin{array}{cc}a_{1} & b_{1} \\ -b_{1}{ }^{*} & a_{1}{ }^{*}\end{array}\right]$ dan $U_{2}=\left[\begin{array}{cc}a_{2} & b_{2} \\ -b_{2}{ }^{*} & a_{2}{ }^{*}\end{array}\right]$, maka harus terbukti bahwa $\varphi\left(U_{1} U_{2}\right)=\varphi\left(U_{1}\right) \varphi\left(U_{2}\right)$. Mulai dari mensubstitusikan matriks $U_{1}$ dan $U_{2}$ yang kemudian ditulis $\varphi\left(U_{1} U_{2}\right)=\varphi\left(\left[\begin{array}{cc}a_{1} & b_{1} \\ -b_{1}{ }^{*} & a_{1}{ }^{*}\end{array}\right]\left[\begin{array}{cc}a_{2} & b_{2} \\ -b_{2}{ }^{*} & a_{2}{ }^{*}\end{array}\right]\right)$ lalu mengoperasikan perkalian matriks biasa pada kedua matriks tersebut, didapatlah $\varphi\left(\left[\begin{array}{cc}a_{1} a_{2}-b_{1} b_{2}{ }^{*} & a_{1} b_{2}+a_{2}{ }^{*} b_{1} \\ -a_{2} b_{1}{ }^{*}-a_{1}{ }^{*} b_{2}{ }^{*} & -b_{1}{ }^{*} b_{2}+a_{1}{ }^{*} a_{2}{ }^{*}\end{array}\right]\right)$. Selanjutnya elemen tersebut dipetakan oleh $\varphi$ sehingga menjadi $\left[\begin{array}{ccc}\operatorname{Re}\left(x^{2}-y^{2}\right) & \operatorname{Im}\left(x^{2}+y^{2}\right) & -2 \operatorname{Re}(x y) \\ -\operatorname{Im}\left(x^{2}-y^{2}\right) & \operatorname{Re}\left(x^{2}+y^{2}\right) & 2 \operatorname{Im}(x y) \\ 2 \operatorname{Re}\left(x y^{*}\right) & 2 \operatorname{Im}\left(x y^{*}\right) & |x|^{2}-|y|^{2}\end{array}\right]$ serta terdapat variabel yang dimisalkan dengan $x=a_{1} a_{2}-b_{1} b_{2}{ }^{*}, y=a_{1} b_{2}+a_{2}{ }^{*} b_{1}$, dan $y^{*}=a_{1}{ }^{*} b_{2}{ }^{*}+a_{2} b_{2}{ }^{*}$. Hasil pemetaan tersebut ternyata merupakan hasil perkalian matriks $\left[\begin{array}{ccc}\operatorname{Re}\left(a_{1}{ }^{2}-b_{1}{ }^{2}\right) & \operatorname{Im}\left(a_{1}{ }^{2}+b_{1}{ }^{2}\right) & -2 \operatorname{Re}\left(a_{1} b_{1}\right) \\ -\operatorname{Im}\left(a_{1}{ }^{2}-b_{1}{ }^{2}\right) & \operatorname{Re}\left(a_{1}{ }^{2}+b_{1}{ }^{2}\right) & 2 \operatorname{Im}\left(a_{1} b_{1}\right) \\ 2 \operatorname{Re}\left(a_{1} b_{1}{ }^{*}\right) & 2 \operatorname{Im}\left(a_{1} b_{1}{ }^{*}\right) & \left|a_{1}\right|^{2}-\left|b_{1}\right|^{2}\end{array}\right] \quad$ dan $\left[\begin{array}{ccc}\operatorname{Re}\left(a_{2}{ }^{2}-b_{2}{ }^{2}\right) & \operatorname{Im}\left(a_{2}{ }^{2}+b_{2}{ }^{2}\right) & -2 \operatorname{Re}\left(a_{2} b_{2}\right) \\ -\operatorname{Im}\left(a_{2}{ }^{2}-b_{2}{ }^{2}\right) & \operatorname{Re}\left(a_{2}{ }^{2}+b_{2}{ }^{2}\right) & 2 \operatorname{Im}\left(a_{2} b_{2}\right) \\ 2 \operatorname{Re}\left(a_{2} b_{2}{ }^{*}\right) & 2 \operatorname{Im}\left(a_{2} b_{2}{ }^{*}\right) & \left|a_{2}\right|^{2}-\left|b_{2}\right|^{2}\end{array}\right]$ dengan operasi perkalian matriks biasa. Terlihat bahwa perkalian kedua matriks tersebut merupakan hasil pemetaan elemen $U_{1}$ dan $U_{2}$ oleh $\varphi$, dapat ditulis $\varphi\left(U_{1}\right) \varphi\left(U_{2}\right)$. Maka didapatlah hasil $\varphi\left(U_{1} U_{2}\right)=\varphi\left(U_{1}\right) \varphi\left(U_{2}\right)$. Sehingga terbuktilah bahwa pemetaan $\varphi$ homomorfisma.

Langkah akhir untuk membuktikan pemetaan $\varphi$ merupakan pemetaan yang homomorfisma surjektif adalah menunjukkan bahwa $\varphi$ merupakan fungsi pada. Ambil $R \in S O(3)$ sembarang kemudian akan ditunjukkan bahwa $R=\varphi(U)$. Dalam pemetaan $\varphi$ telah diketahui bahwa $R$ sebagai

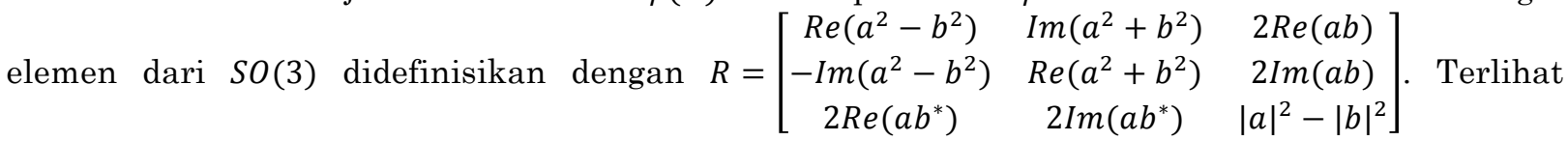
bahwa setiap entri di $R$ dapat dibentuk dari sembarang dua bilangan kompleks, misalnya $a, b$. Maka dapat dibuat matriks $2 \times 2$ dengan entri-entri $a, b \in \mathbb{C}$ dan dibuat sedemikian sehingga menjadi matriks uniter, sehingga didapat $R=\varphi(U)$. Jadi, terbukti bahwa $\varphi$ merupakan fungsi pada.

Berdasarkan penjabaran rinci pembuktian diatas, maka terbukti bahwa $\varphi$ merupakan homomorfisma surjektif. 
Setelah ditunjukkan pemetaan awal merupakan pemetaan homomorfisma surjektif, kemudian dicari kernel dari pemetaan tersebut, yaitu semua elemen $S U(2)$ yang dipetakan ke elemen identitas di $S O(3)$ agar bisa mengkonstruksi grup baru, yaitu grup kuosien. $\operatorname{Ker}(\varphi)=\left\{\left[\begin{array}{cc}a & b \\ -b^{*} & a^{*}\end{array}\right] \mid a= \pm 1, b=0\right\}=\left\{\left[\begin{array}{cc}1 & 0 \\ 0 & 1\end{array}\right],\left[\begin{array}{cc}-1 & 0 \\ 0 & -1\end{array}\right]\right\}=\{I,-I\}$. Kemudian dapat dikonstruksilah grup kuosiennya yaitu $S U(2) / \operatorname{Ker}(\varphi)$.

Kemudian setelah menemukan grup kuosien yang dikonstruksi dari grup $S U(2)$ oleh kernel dari pemetaan yang memetakan $S U(2)$ ke $S O(3)$, maka dapat dilihat kesamaan struktur antara grup kuosien $S U(2) / \operatorname{Ker}(\varphi)$ dengan grup $S O(3)$.

Langkah awal dalam penjabaran akhir pembuktian teorema fundamental homomorfisma ini adalah mengkonstruksi pemetaan. Definisikan pemetaan $\mu$ yang memetakan $S U(2) / \operatorname{Ker}(\varphi)$ ke $S O(3)$ atau dapat ditulis $\mu: S U(2) / \operatorname{Ker}(\varphi) \rightarrow S O(3)$. Selanjutnya pemetaan inilah yang akan diperiksa apakah terdefinisi dengan baik, merupakan pemetaan homomorfisma, merupakan pemetaan injektif, dan merupakan pemetaan surjektif. Berikut ini akan dibahas detail mengenai pembuktian isomorfisma $S U(2) / \operatorname{Ker}(\varphi)$ ke $S O(3)$.

Akan ditunjukkan $\mu$ terdefinisi dengan baik dengan cara mengambil $U_{1} \operatorname{Ker}(\varphi), U_{2} \operatorname{Ker}(\varphi) \in$ $S U(2) / \operatorname{Ker}(\varphi)$ dengan $U_{1} \operatorname{Ker}(\varphi)=U_{2} \operatorname{Ker}(\varphi)$. Kemudian akan ditunjukkan bahwa $\mu\left(U_{1} \operatorname{Ker}(\varphi)\right)=$ $\mu\left(U_{2} \operatorname{Ker}(\varphi)\right)$. Karena pemetaan $\mu: S U(2) / \operatorname{Ker}(\varphi) \rightarrow S O(3)$ dan $\varphi: S U(2) \rightarrow S O(3)$ sehingga berlaku $(U \operatorname{Ker}(\varphi))=R \quad$ dan $R=\varphi(U)$. Didapatlah $\left(U_{1} \operatorname{Ker}(\varphi)\right)=R_{1}=\varphi\left(U_{1}\right)=\varphi\left(U_{2}\right)=R_{2}=\left(U_{2} \operatorname{Ker}(\varphi)\right)$. Maka terlihat bahwa $\mu\left(U_{1} \operatorname{Ker}(\varphi)\right)=\mu\left(U_{2} \operatorname{Ker}(\varphi)\right)$. Sehingga terbukti bahwa $\mu$ terdefinisi dengan baik.

Selanjutnya akan ditunjukkan $\mu$ homomorfisma. Jika $U_{1} \operatorname{Ker}(\varphi), U_{2} \operatorname{Ker}(\varphi) \in^{S U(2)} / \operatorname{Ker}(\varphi)$ maka harus berlaku $\mu\left(U_{1} \operatorname{Ker}(\varphi) \cdot U_{2} \operatorname{Ker}(\varphi)\right)=\mu\left(U_{1} \operatorname{Ker}(\varphi)\right) \cdot \mu\left(U_{2} \operatorname{Ker}(\varphi)\right)$. Karena sifat koset, maka dapat dituliskan persamaan seperti berikut $\mu\left(U_{1} \operatorname{Ker}(\varphi) \cdot U_{2} \operatorname{Ker}(\varphi)\right)=\mu\left(U_{1} \cdot U_{2} \operatorname{Ker}(\varphi)\right)$. Karena berlaku pula pemetaan $\mu(U \operatorname{Ker}(\varphi))=R, R=\varphi(U)$ dan $\varphi(U)=\mu(\operatorname{UKer}(\varphi))$, maka didapatlah persamaan berikut $\mu\left(U_{1} \operatorname{Ker}(\varphi) \cdot U_{2} \operatorname{Ker}(\varphi)\right)=\mu\left(U_{1} \cdot U_{2} \operatorname{Ker}(\varphi)\right)=R_{1} R_{2}=\varphi\left(U_{1}\right) \varphi\left(U_{2}\right)=\mu\left(U_{1} \operatorname{Ker}(\varphi)\right) \cdot \mu\left(U_{2} \operatorname{Ker}(\varphi)\right)$. Telah didapatkan $\mu\left(U_{1} \operatorname{Ker}(\varphi) \cdot U_{2} \operatorname{Ker}(\varphi)\right)=\mu\left(U_{1} \operatorname{Ker}(\varphi)\right) \cdot \mu\left(U_{2} \operatorname{Ker}(\varphi)\right)$ sehingga terbukti bahwa pemetaan $\mu$ merupakan pemetaan homomorfisma.

Kemudian haruslah ditunjukkan bahwa pemetaan $\mu$ merupakan fungsi injektif dengan cara menunjukkan persamaan $U_{1} \operatorname{Ker}(\varphi)=U_{2} \operatorname{Ker}(\varphi)$ harus berlaku. Misalkan diambil sembarang $\mu\left(U_{1} \operatorname{Ker}(\varphi)\right), \mu\left(U_{2} \operatorname{Ker}(\varphi)\right) \in S O(3)$ dengan $\mu\left(U_{1} \operatorname{Ker}(\varphi)\right)=\mu\left(U_{2} \operatorname{Ker}(\varphi)\right)$. Maka dengan berlakunya $\mu(\operatorname{UKer}(\varphi))=R$ dan $R=\varphi(U)$, sehingga didapatkan $\varphi\left(U_{1}\right)=\varphi\left(U_{2}\right)$ dari persamaan awal $\left(U_{1} \operatorname{Ker}(\varphi)\right)=\mu\left(U_{2} \operatorname{Ker}(\varphi)\right)$ kemudian didapatkan $R_{1}=R_{2}$. Selanjutnya, kedua ruas persamaan $\varphi\left(U_{1}\right)=\varphi\left(U_{2}\right)$ dikalikan oleh $\left(\varphi\left(U_{2}\right)\right)^{-1}$ sehingga menghasilkan $\varphi\left(U_{1}\right)\left(\varphi\left(U_{2}\right)\right)^{-1}=I$. Karena sifat invers, maka persamaannya dapat kita tulis kembali menjadi $\varphi\left(U_{1}\right) \varphi\left(U_{2}{ }^{-1}\right)=I$ dan lebih disederhanakan lagi menjadi $\varphi\left(U_{1} U_{2}{ }^{-1}\right)=I$. Karena $\varphi\left(U_{1} U_{2}{ }^{-1}\right)=I$, maka $U_{1} U_{2}^{-1} \in \operatorname{Ker}(\varphi)$ sehingga mengakibatkan $U_{1} \operatorname{Ker}(\varphi)=U_{2} \operatorname{Ker}(\varphi)$. Jadi, terbuktilah bahwa pemetaan $\mu$ merupakan fungsi injektif.

Langkah akhir dalam membuktikan isomorfisma pemetaan $\mu$ adalah dengan menunjukkan bahwa pemetaan $\mu$ merupakan fungsi pada dan harus memenuhi apabila terdapat $U \operatorname{Ker}(\varphi)$ elemen $S U(2) / \operatorname{Ker}(\varphi)$, maka haruslah berlaku $\mu(\operatorname{UKer}(\varphi))=\varphi(U)=R$. Karena telah diketahui bahwa 
pemetaan $\varphi$ merupakan fungsi pada dan terdapat $U \in S U(2)$, maka berlaku $R=\varphi(U)$. Karena $U \in S U(2)$ dan $\operatorname{Ker}(\varphi) \triangleleft S U(2)$, maka dapat dikonstruksi grup kuosien yaitu $S U(2) / \operatorname{Ker}(\varphi)$ dengan elemennya $U \operatorname{Ker}(\varphi)$ sedemikian sehingga didapatlah pemetaan $\mu(U \operatorname{Ker}(\varphi))=\varphi(U)=R$. Jadi terbukti bahwa pemetaan $\mu$ merupakan fungsi pada.

Berdasarkan pemaparan pembuktian rinci di atas, maka terbukti bahwa pemetaan $\mu: S U(2) / \operatorname{Ker}(\varphi) \rightarrow S O(3)$ merupakan isomorfisma serta $S U(2) / \operatorname{Ker}(\varphi)$ isomorfik terhadap $S O(3)$.

Isomorfisma dalam pembuktian ini dapat dibuat dalam diagram sebagai berikut:

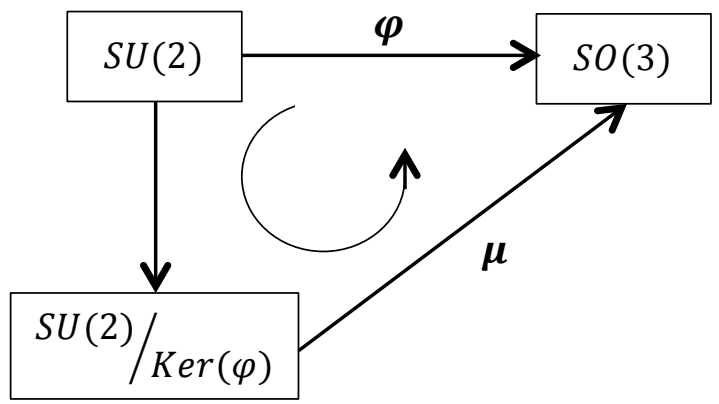

Gambar 1. Diagram Alur Isomorfisma

Manfaat setelah mengetahui bahwa dua grup yang berbeda tetapi saling isomorfik adalah dapat memudahkan untuk melihat sifat-sifat yang terdapat pada masing-masing grup. Sifat dalam grup yang saling isomorfik adalah sama. Jadi dengan kata lain, pendekatan grupnya bisa dilihat melalui grup yang telah terbukti saling isomorfik untuk memudahkan pengerjaan.

\section{Simpulan}

Apabila dalam ilmu pasti menyatakan bahwa rotasi elektron memiliki dua jenis, yaitu momentum spin dan momentum sudut, maka paper ini memaparkan bahwa teori grup dapat digunakan dalam melihat keterkaitan antara grup yang merepresentasikan momentum spin yaitu grup spesial uniter dimensi dua yang dinotasikan dengan $S U(2)$ dengan grup yang merepresentasikan momentum sudut orbital yaitu grup spesial ortogonal dimensi tiga yang dinotasikan dengan $S O(3)$. Untuk melihat keterkaitan antara kedua grup tersebut, grup $S U(2)$ harus dikonstruksi terlebih dahulu menjadi grup kuosiennya yaitu $S U(2) / \operatorname{Ker}(\varphi)$ yang kemudian grup kuosien tersebutlah yang isomorfik dengan grup $S O(3)$, artinya mereka memiliki struktur grup dan sifat-sifat grup yang sama.

Dalam paper ini, setelah mengetahui bahwa pemetaan $\mu: S U(2) / \operatorname{Ker}(\varphi) \rightarrow S O(3)$ saling isomorfik, maka ditelitilah sifat-sifat isomorfisma dalam elemen grupnya maupun dalam grupnya itu sendiri. Apabila dua buah grup saling isomorfik, dalam hal ini yaitu grup $S U(2) / \operatorname{Ker}(\varphi)$ dan grup $S O(3)$, maka pemeriksaan struktur atau sifat pada kedua grup tersebut akan menghasilkan struktur dan sifat yang sama. Kedua grup tersebut bukan merupakan grup abelian dan kedua grup tersebut memenuhi sifat isomorfisma sebuah pemetaan. 


\section{Daftar Pustaka}

1. Baumslag, B. dan Chandler, B. 1968. Theory and Problems of Group Theory. Sydney: McGrawHill, Inc.

2. Neumaier, A. dan Westra, D. 2008. Classical and Quantum Mechanics via Lie Algebras (hlm. 114-117). Austria: University of Vienna.

3. Rosyid, Farchani Muhammad. 2005. Mekanika Kuantum. Yogyakarta: Jurusan Fisika FMIPA UGM Yogyakarta.

4. Woit, Peter. 2016. Quantum Theory, Groups, and Representations: An Introduction (Under Construction). New York: Columbia University. 